\title{
IMPACT OF USING ENCAPSULATED AND NON-ENCAPSULATED PROBIOTICS ON THE PERFORMANCE OF YOUNG SUCKLING CALVES
}

\author{
EL-GARHI, M.S. ${ }^{1}$; MONA S. ZAYED ${ }^{2}$; HODA S. EL-SAYED ${ }^{3}$; SHERIF, H.R. ${ }^{1}$ \\ and N.E. EL-BORDENY ${ }^{4}$ \\ ${ }^{1}$ Animal Reproduction Research Institute, Agricultural Research Center, Giza, Egypt. \\ ${ }^{2}$ Department of Agriculture Microbiology, Faculty of Agric., Ain Shams Univ., P.O. Box 68 Hadayek Shoubra, 11241, \\ Cairo, Egypt. \\ ${ }^{3}$ Department of Dairy Sciences, National Research Center, 33 buhouth St., Dokki, Giza, 12311, Egypt. \\ ${ }^{4}$ Department of Animal Production, Faculty of Agric., Ain Shams Univ., P.O. Box 68 Hadayek Shoubra, 11241,
} Cairo, Egypt.

Received: 21 May 2019; Accepted: 23 June 2019

\begin{abstract}
The aim of this study was to evaluate the effect of encapsulated and non-encapsulated probiotics on preruminant calves' performance and health status. Three probiotic bacteria were isolated, characterized, identified and propagated to be used as a probiotic supplementation in different forms (non-encapsulated and capsulated). Forty-five Holstein newly born calves were divided into three treatments (15 each). Control group T1 (calves were fed milk without any supplementation), T2 (calves were fed milk supplemented with 1 ml $* 10^{6}$ probiotic in liquid media) and T3 (calves were fed milk supplemented with $1 \mathrm{~g} * 10^{6}$ encapsulated probiotic). The newly born calves were fed their colostrum for three days, then they were fed 3.8-4.3 kg milk per day and the quantity increased gradually to $5.750 \mathrm{~kg}$ milk, calves had a free access to starter feed from the fifth day post calving and weaned when eat $1.5 \mathrm{~kg}$ starter feed for three consecutive days. Calves were weighed monthly until weaning and growth rate was calculated. Fecal samples were collected monthly and at the end of the experimental period to ensure they are free from pathogenic E.coli and salmonella Spp., also the fecal samples were collected every day for one week after the end of the experiment for measuring total count of lactic acid bacteria. Blood samples were collected for complete $\mathrm{CBC}$ analysis and measuring immune parameters. Results revealed that, daily growth rate of calves in $\mathrm{T} 3$ tend to be significantly higher $(\mathrm{P}=0.075)$ than the other two groups. There is no significant differences between treatments and control in the lactic acid bacterial shedding in the fecal matter during the $1^{\text {st }}, 2^{\text {nd }}$ and $3^{\text {rd }}$ months of experiment and the week next to the end of the experiment. Complete CBC data showed normal values for the three groups, while a significant increase were shown in MXD and neutrophils at the $1^{\text {st }}$ month from calving in group (2) than other two groups. The effect of treatments on some biochemical blood parameters showed that, calves in the second group have lower $(\mathrm{P}<0.05)$ blood AST concentration at $1^{\text {st }}$ month than in T1 and T3, also ALP1 and ALP2 concentrations tended to be significantly $(\mathrm{P}=0.079, \mathrm{p}=0.055$ respectively) higher in the control groups $(\mathrm{T} 1)$ than treated groups. Moreover data showed that calves in group T3 have lower urea concentrations at 2nd month than in T1 and T2, while cholesterol and T.G concentration was lower in calves in group T2 than control. Effect of treatments on some immunological blood parameters showed no significant differences between treatments and control in the concentrations of lysozyme, nitric oxide and IgG in the three different samples, while lysozymes activities showed increases in the treated groups than control with no significant differences. So it can be concluded that, probiotics supplementations improve calves health, immunity, growth performance and do not affect its biochemical and hematological parameters.
\end{abstract}

Key words: Probiotics, calve performance, immunity

\section{INTRODUCTION}

In the newborn calves, the digestive tracts are sterile in the uterus of their mothers. After birth, microorganisms colonize in the rumen and lower part of gut in a symbiotic relationship with the host.

Corresponding author: Dr. EL-GARHI, M.S. E-mail address: m_elgarhi2005@yahoo.com

Present address: Animal Reproduction Research Institute, Agricultural Research Center, Giza, Egypt.
By up growing the intensive rearing and management methods, calves become very sensitive to enteric bacterial imbalance and usually suffer from diarrhea and enteric diseases. According to FAO/WHO (2001), probiotics are "live microorganisms which when be fed in adequate amounts conferring a health benefits on the host".

The usage of antibiotics for prevention of infections in animals should be avoided; thus, the possibility of 
using lactic acid bacteria (LAB) as an alternative treatment is promising (Bujnakova et al., 2014). The health of calves under 90 days of age has been shown to have long-term impacts on their future productivity (Stanton 2014). The use of (LAB) has been identified as a tool to maintain the intestinal microbial balance and to prevent the establishment of opportunistic pathogenic bacterial populations (Signorini et al., 2012). However, a consensus has not been reached as to whether probiotics may be effective in reducing the incidence of disease in young calves and enhance their performance.

Since the beneficial effects of probiotics are strain dependent, it has been suggested that combinations of different probiotic strains may be more effective than single strain probiotics (Timmerman et al., 2004). The rationale for multiple organisms comes from potential synergistic actions. It seems that probiotic strains of animal origin due to "host specific effect" are more effective (Fuller, 1997), and there are some studies that showed animals generally benefits from probiotic microorganisms isolated from their own digestive tracts (Walter, 2005). However, Timmerman et al. (2005) used a multispecies probiotic and a calf specific multistrain probiotic and found no clear difference in the efficiency. There are limited researches in calves fed multi-strains of probiotics from calves' origin, so the purpose of this study was feeding probiotics (a laboratory produced probiotics) of calves' origin isolated from a farm to be used in the same farm and its evaluation on calves' performance.

\section{MATERIALS AND METHODS}

\section{-Microbial strains and growth condition}

Eleven probiotic isolates were isolated from calves saliva and feces revealed on 3 bacterial strains characterized and identified to be propagated and used as a probiotic supplementation in different forms (non-encapsulated and capsulated). Lactobacilli isolates were grown on MRS broth (Oxoid) and Streptococci isolates were grown on M17 broth (Difco), after that the broth media incubated for $24 \mathrm{~h}$ at $37{ }^{\circ} \mathrm{C}$. The strains were activated two or three times in order to obtain high biomasses in the stationary phase then the cell pellets were harvested by centrifugation at 5000rpm, for $20 \mathrm{~min}$ at $4{ }^{\circ} \mathrm{C}$. The pellets were washed by sterile saline solution $(0.9 \% \quad(\mathrm{w} / \mathrm{v}) \quad \mathrm{NaCl})$ and recovered under the same centrifugation conditions then stored at $\approx 8{ }^{\circ} \mathrm{C}$ till be encapsulated Chávarri et al. (2010).

Genetic identification of isolated and tested strains

The isolates were identified according to 16sRNA in Sigma Company (Germany) by the automated sequencer (Table 1).

Table 1: The genetic identification of the tested probiotics stains.

\begin{tabular}{cccc}
\hline Probiotic strain & Code & Isolation source & Isolation media \\
\hline $\begin{array}{c}\text { Lactobacillus farraginis strain NRIC 0676 } \\
\text { 16S ribosomal RNA gene, partial sequence, } \\
\text { NR 041467.1 }\end{array}$ & A1 & Saliva, Feces & \\
\hline $\begin{array}{c}\text { Lactobacillus reuteri strain NBRC 15892 } \\
\text { 16S ribosomal RNA gene. Partial sequence, }\end{array}$ & A2 & MRS- M17 \\
NR 113820.1 & & Saliva & M17 \\
\hline $\begin{array}{c}\text { Lactobacillus rhamnosus strain NBRC 3425 } \\
\text { 16S ribosomal RNA gene, partial sequence, } \\
\text { NR 113332.1 }\end{array}$ & A3 & feces & M17 \\
\hline
\end{tabular}

\section{Preparation of Encapsulated mixed strains using extrusion method:}

Generally, the microencapsulation process was performed using the extrusion technique (EL-Shafei et al., 2018). One part of the cells of different isolates suspension was mixed with three parts of the freshly prepared sodium alginate $(3 \%)$ with gentle stirring for 10-20 min. The mixture was then extruded into the hardening solution $\left(\mathrm{CaCl}_{2}, 0.2 \mathrm{M}\right)$ through sterile syringe $(25 \mathrm{G}, 0.5 \mathrm{~mm})$ with gentle stirring for $30 \mathrm{~min}$ to ensure complete solidification.
The formed microcapsules were harvested by filtration then washed by sterile saline solution.

\section{Enumeration of the microencapsulated cells}

The viability of mixed strains was assessed as described by Chávarri et al. (2010). One gram of the microcapsules was dissolved in $9 \mathrm{ml}$ of sterile trisodium citrate solution $(2 \% \mathrm{w} / \mathrm{v})$ and vortexed till complete dissolution then the samples were serially diluted to appreciate concentration using saline solution and pour plated in MRS agar for lactobacilli 
and in M17 agar for streptococci. The plates were incubated $48 \mathrm{~h}$ at $37{ }^{\circ} \mathrm{C}$. The viable cell number was expressed as colony forming unit per gram of microcapsule (cfu/g).

\section{Experimental animals and design.}

Forty-five Frisian newborn calves were sexed, weighed and numbered within 12 hrs. after birth. The animals were randomly assigned into three experimental groups (15 animals each) when they have 3 days old. Control treatment, calves were fed the milk without any supplementation, in nonencapsulated treatment, calves were fed the milk supplemented with $1 \mathrm{ml}$ liquid probiotic bacteria contain $10^{6} \mathrm{CFU}$ and in encapsulated treatment, calves were fed the milk supplemented with $1 \mathrm{~g}$ encapsulated probiotic contain $10^{6} \mathrm{CFU}$ of probiotic bacteria (using $2.5 \%$ sodium alginate solution crosslinked by calcium chloride). Calves were housed in a naturally ventilated barn and kept in individual pens. After the newly born calves get their colostrum for 3 days, the calves were fed $3.8 \mathrm{~kg}$ milk artificially and the quantities of milk were increased gradually up to $5.750 \mathrm{~kg}$ milk per head per day at two months of calves' age. Calves had access to clean fresh water and dry starter feed at all times. All calves were weaned gradually, to decrease the effects of weaning stress, when they consumed $1500 \mathrm{~g}$ of starter per day for three consecutive days. The experiment was extended for three months. Calves were weighed monthly and average daily gain was calculated.

\section{Sampling, measurement, and analyses}

Fecal samples were collected monthly and at the end of treatments. Fecal samples were collected from rectum with sterile rubber gloves and place in sterile plastic tubes, maintained in ice box and immediately transported to the laboratory to be tested for the presence of salmonella (Paul et al., 2000) and pathogenic strains of E.coli (Cowan, 1983) as well as the total probiotic bacteria count. The fecal samples also were collected every day for one week after stopping of probiotics supplementation for measuring total count of probiotic bacteria and its shedding.

Two Blood samples were collected from 10 animals of each group, after 30, 60 and 90 days of the treatments beginning. Serum was separated from the first blood sample and frozen at $-20^{\circ} \mathrm{C}$ till further analysis, while the second sample were derived to the laboratory for WBCs count, neutrophils, and lymphocytes and monocytes concentration using auto hematology analyzer (BC-2800, Nanshan, Shenzhen 518057, P.R. China). Serum samples were stored frozen for ELISA analysis of immunoglobulin G1, nitric oxide and lysozymes concentrations. The ELISA analysis was described by Rivera et al. (2002), nitric oxide was measured according to Rajarman et al. (1998) and lysozymes measuring described by Schultz (1987). Blood serum samples were analyzed using commercial kits. Total serum protein concentrations was determined as described by Cannon et al. (1974), albumin concentrations was determined using methods of Doumas et al. (1971), blood plasma urea was determined according to Batton and Crouch (1977), alkaline phosphatase was determined according to Belfield and Goldberg (1971), Triglycerides was determined according to Stein and Athans (1987), creatinine was determined according to Spencer and Price (1980), Alanine amino transferase (ALT) and aspartate amino transferase (AST) activities were calorimetrically determined according to AST and ALT kits based on reaction of Young (1990).

\section{Statistical analysis.}

Obtained data were statistically analyzed using the statistical package SPSS for Windows XP V15.0 (SPSS Inc., Chicago, USA, 2007). The significance of differences between treated samples was evaluated using Anova test.

\section{RESULTS}

\section{Calves health}

The data of table (2) showed that no pathogenic bacteria (Salmonella sp. and E.coli) were detected in calves' fecal matter.

\section{Effect of probiotic supplementation on probiotic bacterial count during and after the experimental period}

Total probiotic bacterial count of calves' fecal matter during and after treatment time are presented in Table (2) and Figure (1). The data indicated that during the experimental period although the animals supplemented with encapsulated and nonencapsulated probiotic recorded numerical increase in $\log$ CFU of probiotic bacteria per gram fecal matter no significant differences were recorded at different sampling time. Also, the results of Table (2) and Figure (1) indicated that the probiotic bacteria in calf's fecal matter supplemented with encapsulated and non-encapsulated probiotics was slowly reduced than other in control group but the difference between groups were non significantly different. 
Table 2: Total count of lactic acid bacterial shedding in calves' fecal matters during and after probiotic supplementation.

\begin{tabular}{|c|c|c|c|c|}
\hline Item & Control & Non-encapsulated & encapsulated & $P$ value \\
\hline Salmonella spp. count & $\mathrm{ND}^{1}$ & ND & ND & -- \\
\hline pathogenic E.coli count & ND & ND & ND & - \\
\hline \multicolumn{5}{|c|}{ Total probiotic bacteria count during the experimental period. } \\
\hline Count at 30 days, $\log \mathrm{CFU} / \mathrm{ml}$ & $6.42 \pm 0.38$ & $6.48 \pm 0.44$ & $6.73 \pm 0.36$ & 0.84 \\
\hline Count at 60 days, $\log$ CFU/ml & $6.52 \pm 0.37$ & $6.37 \pm 0.51$ & $6.74 \pm 0.39$ & 0.83 \\
\hline Count at 90 days, $\log$ CFU/ml & $6.83 \pm 0.60$ & $6.42 \pm 0.32$ & $6.77 \pm 0.34$ & 0.73 \\
\hline \multicolumn{5}{|c|}{ Probiotic bacterial shedding in calves' fecal matter after end of the treatment } \\
\hline Count at $1^{\text {st }}$ day, $\log \mathrm{CFU} / \mathrm{ml}$ & 8.35 & 8.15 & 7.84 & \\
\hline Count at $2^{\text {nd }}$ day, $\log \mathrm{CFU} / \mathrm{ml}$ & 7.01 & 7.63 & 7.95 & \\
\hline Count at $3^{\text {rd }}$ day, $\log \mathrm{CFU} / \mathrm{ml}$ & 6.69 & 6.72 & 7.13 & \\
\hline Count at $4^{\text {th }}$ day, $\log \mathrm{CFU} / \mathrm{ml}$ & 5.03 & 5.85 & 6.25 & \\
\hline Count at $5^{\text {th }}$ day, $\log \mathrm{CFU} / \mathrm{ml}$ & 4.06 & 5.72 & 6.11 & \\
\hline
\end{tabular}

ND, non-detected.

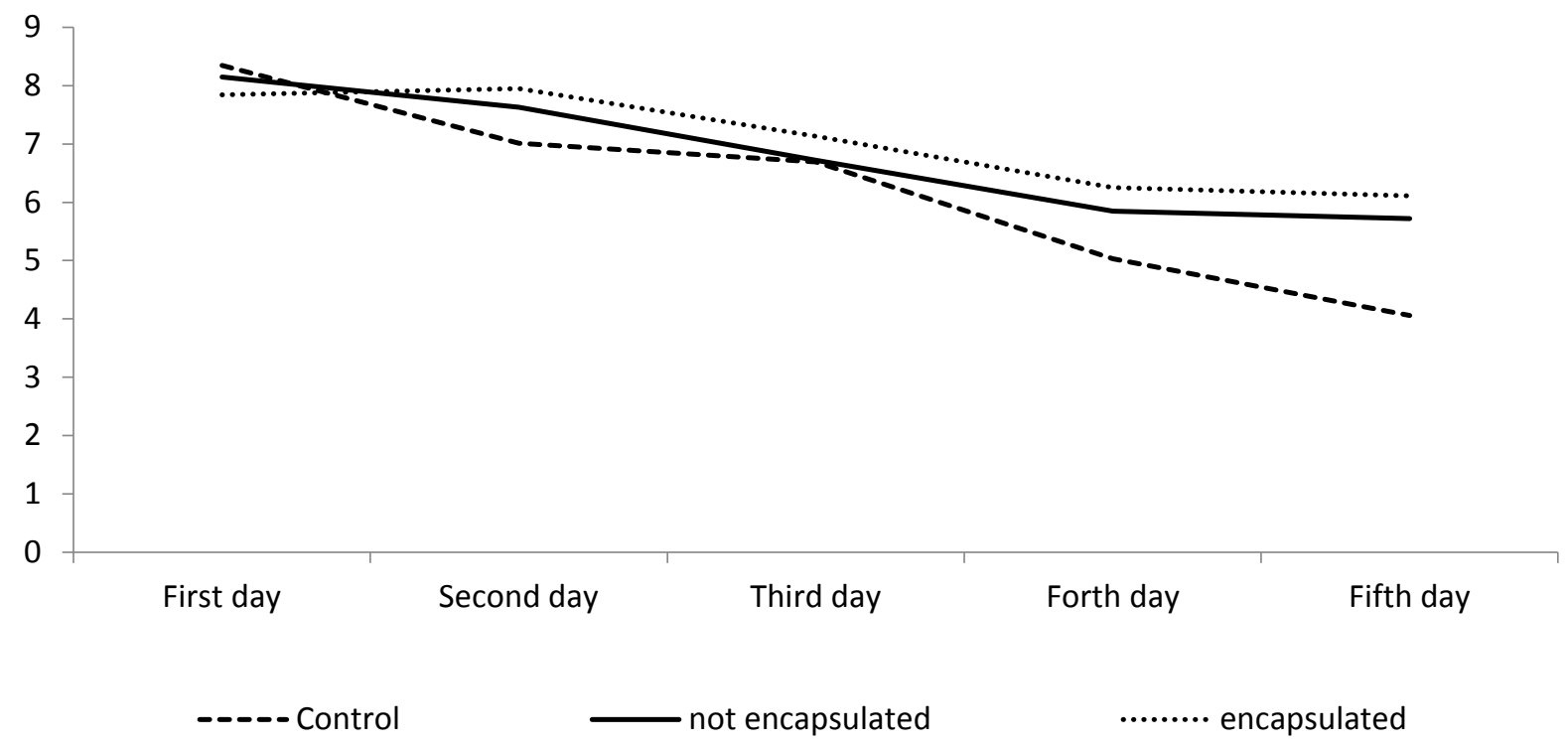

Figure (1): Effect of encapsulated and non-encapsulated probiotics on probiotic bacterial shedding from the intestine afte the end of the experiment

Effect of probiotic supplementation on blood CBC count.

The data of Table (3) and (4) showed effect of probiotic supplementation on blood CBC count at one month from calving and at the end of the test period. The data shows that hematology parameters were normal in the three groups with no significant differences among the different experimental treatments at one month old for calves in the group supplemented with non- encapsulated probiotic than the control and encapsulated probiotic group.

The data of Tables (3) showed a significant increase in mixed cell count (MXD) at one month old for calves in the group supplemented with nonencapsulated probiotic than the control and encapsulated probiotic group, while neutrophils tend to be significantly $(\mathrm{P}<0.08)$ higher in the nonencapsulated group than the two others groups. 
Table 3: Effect of probiotic supplementation on blood CBC counts of calves at one month age.

\begin{tabular}{lcccc}
\hline Item & $\begin{array}{c}\text { Control } \\
\text { Mean } \pm \text { SEM }\end{array}$ & 3 & $\begin{array}{c}\text { Encapsulated } \\
\text { Mean } \pm \text { SEM }\end{array}$ & P value \\
\hline RBC $(\mathrm{M} / \mu \mathrm{L})$ & $3.48 \pm 0.28$ & $3.54 \pm 0.22$ & $3.33 \pm 0.48$ & 0.9 \\
\hline HGB $(\mathrm{g} / \mathrm{dL})$ & $10.28 \pm 0.59$ & $9.88 \pm 0.56$ & $10.30 \pm 0.89$ & 0.88 \\
\hline HCT $(\%)$ & $16.51 \pm 1.38$ & $16.84 \pm 1.10$ & $15.80 \pm 2.57$ & 0.91 \\
\hline MCV $(\mathrm{fL})$ & $47.42 \pm 0.30$ & $47.48 \pm 0.23$ & $47.60 \pm 0.67$ & 0.95 \\
\hline MCH $(\mathrm{ps})$ & $29.90 \pm 1.53$ & $27.88 \pm 0.76$ & $32.10 \pm 2.20$ & 0.19 \\
\hline MCHC $(\mathrm{g} / \mathrm{dL})$ & $63.00 \pm 3.08$ & $58.80 \pm 1.46$ & $67.50 \pm 5.56$ & 0.26 \\
\hline LYM $(\mathrm{K} / \mu \mathrm{L}$ & $29.26 \pm 4.26$ & $26.07 \pm 3.26$ & $20.92 \pm 6.64$ & $0.49 \pm 0.32$ \\
\hline MXD $(\%)$ & $0.97 \pm 0.3$ & $1.53 \pm 0.13$ & $0.96 \pm 0.56$ & 0.045 \\
\hline Neut. $(\%)$ & $1.64 \pm 0.65$ & $3.62 \pm 0.98$ & $28.83 \pm 2.43$ & 0.88 \\
\hline WBC $(\mathrm{K} / \mu \mathrm{L})$ & $28.20 \pm 7.10$ & $31.22 \pm 3.81$ & & 0.49 \\
\hline
\end{tabular}

SEM = Standard Error Mean, RBC $=$ Red blood cell, HGB $=$ Hemoglobin, HCT $=$ Hematocrit, MCV $=$ Mean cell volume, $\mathrm{MCH}=$ Mean cell hemoglobin, $\mathrm{MCHC}=$ Mean cell hemoglobin $\mathrm{WBC}=$ White blood cell concentration, LYM $=$ Lymphocyte, NEUT = Neutrophils, MXD = Mixed cell count.

Table 4: Effect of probiotic supplementation on blood CBC counts at the end of experimental period.

\begin{tabular}{lcccc}
\hline Item & Control & Non-encapsulated & encapsulated & P value \\
\hline RBC $(\mathrm{M} / \mu \mathrm{L})$ & $3.60 \pm 0.18$ & $3.04 \pm 0.42$ & $3.53 \pm 0.27$ & 0.46 \\
\hline HGB $(\mathrm{g} / \mathrm{dL})$ & $10.78 \pm 0.66$ & $9.20 \pm 0.79$ & $10.50 \pm 0.35$ & 0.26 \\
\hline HCT $(\%)$ & $17.40 \pm 0.91$ & $14.51 \pm 2.13$ & $16.84 \pm 1.30$ & 0.46 \\
\hline MCV $(\mathrm{fL})$ & $48.18 \pm 0.25$ & $47.56 \pm 0.60$ & $48.03 \pm 0.17$ & 0.61 \\
\hline MCH $(\mathrm{ps})$ & $29.83 \pm 1.06$ & $31.40 \pm 2.36$ & $30.17 \pm 1.39$ & 0.82 \\
\hline MCHC(g/dL) & $62.25 \pm 2.09$ & $66.20 \pm 5.85$ & $63.00 \pm 3.22$ & 0.81 \\
\hline LYM $(\mathrm{K} / \mu \mathrm{L})$ & $32.83 \pm 13.36$ & $22.68 \pm 3.33$ & $17.32 \pm 6.17$ & 0.49 \\
\hline MXD $(\%)$ & $1.02 \pm 0.28$ & $0.85 \pm 0.25$ & $1.07 \pm 0.25$ & 0.83 \\
\hline Neut. $(\%)$ & $2.08 \pm 0.69$ & $1.39 \pm 0.45$ & $2.22 \pm 0.66$ & 0.57 \\
\hline WBC $(\mathrm{K} / \mu \mathrm{L})$ & $23.57 \pm 1.33$ & $24.92 \pm 3.06$ & $20.60 \pm 5.28$ & 0.69 \\
\hline
\end{tabular}

$\mathrm{SEM}=$ Standard Error Mean, $\mathrm{RBC}=$ Red blood cell, $\mathrm{HGB}=$ Hemoglobin, $\mathrm{HCT}=$ Hematocrit, $\mathrm{MCV}=$ Mean cell volume $\mathrm{MCH}=$ Mean cell hemoglobin, $\mathrm{MCHC}=$ Mean cell hemoglobin $\mathrm{WBC}=$ White blood cell concentration, $\mathrm{LYM}=$ Lymphocyte, NEUT = Neutrophils, MXD = Mixed cell count.

Effect of encapsulated and non-encapsulated probiotics supplementation on some blood metabolites

Obtained data of table (5) showed the effect of dietary supplementation of capsulated and nonencapsulated probiotics on some biochemical blood parameters of calves. There is no significant differences in the blood concentrations of total protein (TP) and Albumin between treatments during the three different sampling time. The results (Table 5) revealed that, there were no treatment effects in the total protein of calves in both the control and the experimental groups, while triglycerides (T.G) tend to be significantly lower in both treated groups than control $(\mathrm{P}<0.07)$. 
Table 5: Effect of probiotic supplementation on some biochemical blood parameters of calves.

\begin{tabular}{|c|c|c|c|c|}
\hline Item & Control & Non-encapsulated & encapsulated & $P$ value \\
\hline \multicolumn{5}{|c|}{ Total protein concentration, $\mathrm{g} / \mathrm{dl}$} \\
\hline \multicolumn{5}{|l|}{30 days old } \\
\hline 60 days old & $7.82 \pm 0.40$ & $7.04 \pm 0.34$ & $7.53 \pm 0.33$ & 0.36 \\
\hline 90 days old & 9.36 & $7.89 \pm 0.77$ & $8.55 \pm 0.17$ & 0.51 \\
\hline \multicolumn{5}{|c|}{ Albumin concentration, $\mathrm{g} / \mathrm{dl}$} \\
\hline 30 days old & $4.00 \pm 0.28$ & $3.68 \pm 0.22$ & $4.06 \pm 0.27$ & 0.52 \\
\hline 60 days old & $3.62 \pm 0.33$ & $4.08 \pm 0.22$ & $4.63 \pm 0.38$ & 0.1 \\
\hline 90 days old & $4.04 \pm 0.27$ & $4.57 \pm 0.47$ & $4.82 \pm 0.56$ & 0.63 \\
\hline \multicolumn{5}{|c|}{ Tri-glyceride concentration, mg/dl } \\
\hline 30 days old & $60.11 \pm 12.89$ & $47.54 \pm 9.97$ & $58.40 \pm 8.60$ & 0.67 \\
\hline 60 days old & $103.68 \pm 9.78$ & $79.25 \pm 5.73$ & $85.51 \pm 6.25$ & 0.07 \\
\hline 90 days old & $67.80 \pm 14.08$ & $93.90 \pm 9.34$ & $77.75 \pm 8.35$ & 0.24 \\
\hline \multicolumn{5}{|c|}{ Urea concentration, $\mathrm{mg} / \mathrm{dl}$} \\
\hline 30 days old & $45.72 \pm 4.30$ & $39.84 \pm 2.78$ & $50.43 \pm 4.97$ & 0.21 \\
\hline 60 days old & $53.18 \pm 11.02$ & $51.85 \pm 7.00$ & $59.38 \pm 3.05$ & 0.79 \\
\hline 90 days old & $14.14 \pm 2.72$ & $29.51 \pm 4.92$ & $4.65 \pm .68$ & \\
\hline \multicolumn{5}{|c|}{ Cholesterol concentration, $\mathrm{mg} / \mathrm{dl}$} \\
\hline 30 days old & $97.03 \pm 15.30$ & $119.26 \pm 13.30$ & $100.47 \pm 10.91$ & 0.46 \\
\hline 60 days old & $65.25 \pm 4.90$ & $47.97 \pm 3.90$ & $63.78 \pm 5.24$ & 0.03 \\
\hline 90 days old & $50.53 \pm 3.87$ & $41.96 \pm 9.09$ & $34.66 \pm 6.65$ & 0.31 \\
\hline \multicolumn{5}{|c|}{ AST activity, U/1 } \\
\hline 30 days old & $10.83 \pm 1.76$ & $4.25 \pm 0.25$ & $10.90 \pm 1.19$ & 0.03 \\
\hline 60 days old & $7.21 \pm 2.049$ & $6.11 \pm 1.52$ & $7.79 \pm 1.76$ & 0.78 \\
\hline 90 days old & $7.03 \pm 3.86$ & $6.94 \pm 1.37$ & $8.46 \pm 1.36$ & 0.89 \\
\hline \multicolumn{5}{|c|}{ ALT activity, U/L } \\
\hline 30 days old & $2.88 \pm 0.58$ & $1.64 \pm 0.69$ & $6.20 \pm 4.21$ & 0.16 \\
\hline 60 days old & $22.40 \pm 3.56$ & $27.48 \pm 01.93$ & $25.40 \pm 3.20$ & 0.49 \\
\hline 90 days old & $6.71 \pm 1.82$ & $4.07 \pm 0.96$ & $6.64 \pm 1.11$ & 0.31 \\
\hline \multicolumn{5}{|c|}{ Alkaline-phosphatase activity, U/L } \\
\hline 30 days old & $33.26 \pm 4.51$ & $19.90 \pm 3.97$ & $21.38 \pm 4.64$ & 0.079 \\
\hline 60 days old & $20.22 \pm 3.31$ & $16.26 \pm 1.94$ & $12.18 \pm 1.39$ & 0.055 \\
\hline 90 days old & $51.58 \pm 6.52$ & $42.66 \pm 3.97$ & $35.66 \pm 5.74$ & 0.14 \\
\hline
\end{tabular}

Results in table (5) showed that blood aspartate amino transferase (AST) concentrations at $1^{\text {st }}$ month was significantly $(\mathrm{P}<0.05)$ high in $\mathrm{T} 1$ and $\mathrm{T} 3$ than T2 which indicated better liver health of calves in group T2. Results revealed that, calves received probiotics had lower alkaline phosphatase at the $1^{\text {st }}$ month samples and at the end of the experiment, ALP concentrations tended to be significantly $(\mathrm{P}=0.079, \mathrm{p}=0.055$ respectively) higher in the control group than non-encapsulated and encapsulated groups.

Table (5) revealed that, calves in group T3 have lower urea concentrations than in $\mathrm{T} 1$ and $\mathrm{T} 2$. Also cholesterol concentration was significantly $(\mathrm{P}<0.05)$ lower in calves in non-encapsulated group than in encapsulated and control groups at the $2^{\text {nd }}$ month samples, while it was lower in both treated groups than control in the $3^{\text {rd }}$ month sample with no significant differences $(\mathrm{P}<0.05)$. 
Table 6: Effect of probiotics supplementation on some immunological blood parameters of calves

\begin{tabular}{lcccc}
\hline Item & Control & Non-encapsulated & encapsulated & P value \\
\hline lysozyme activities & & & & \\
\hline 30 days old & $7.71 \pm 4.08$ & $6.93 \pm 3.62$ & $13.68 \pm 5.35$ & 0.51 \\
\hline 60 days old & $77.10 \pm 11.65$ & $91.90 \pm 12.50$ & $91.90 \pm 11.61$ & 0.66 \\
\hline 90 days old & $79.90 \pm 17.68$ & $83.08 \pm 16.13$ & $84.19 \pm 19.45$ & 0.99 \\
\hline nitric oxide concentrations, & & & $14.98 \pm 0.81$ & 0.22 \\
\hline 30 days old & $13.67 \pm 0.46$ & $13.68 \pm 0.41$ & $30.74 \pm 1.93$ & 0.62 \\
\hline 60 days old & $27.74 \pm 2.05$ & $30.24 \pm 2.32$ & $27.80 \pm 3.83$ & 0.99 \\
\hline 90 days old & $27.14 \pm 3.48$ & $27.80 \pm 3.20$ & & 0.38 \\
\hline IgG concentrations, & & & 30.09 & 0.1 \\
\hline 30 days old & $30.71 \pm 0.50$ & $29.69 \pm 0.41$ & $38.34 \pm 1.11$ & 0.24 \\
\hline 60 days old & $38.94 \pm 0.58$ & $41.61 \pm 0.35$ & $41.12 \pm 0.83$ & \\
\hline 90 days old & $44.74 \pm 0.62$ & $42.98 \pm 1.63$ & & \\
\hline
\end{tabular}

Results in table 6 showed that, there was no significant different between treatments in lysozyme activities, nitric oxide and IgG concentrations in the three different samples, lysozymes activity show a non-significant increase in the treated groups than control. Data showed that, lysozyme, nitric oxide and IgG were increased by increasing age.

Effect of encapsulated and non-encapsulated isolated probiotics on growth performance of young calves.
Effect of encapsulated and non-encapsulated probiotics on growth rate of young calves are illustrated in table (7).

The results indicated that the encapsulated and nonencapsulated probiotics have a positive effect on calves weight at 60 days post calving $(\mathrm{p}<0.05)$. Weaning weight was higher in group fed encapsulated probiotics comparing to the nonencapsulated probiotics and control, growth rate was enhanced by treating calves by encapsulated probiotics than non-encapsulated one, while, no significance difference among treatments was shown.

Table 7: Effect of encapsulated and non-encapsulated isolated probiotics on calve growth performance.

\begin{tabular}{|c|c|c|c|c|}
\hline Group & control & Non encapsulated & Encapsulated & $\mathrm{P}$ value \\
\hline Birth weight & $31.54 \pm 1.37$ & $29.95 \pm 1.43$ & $29.11 \pm 1.65$ & 0.5068 \\
\hline Body weight at 30 days & $37.27 \pm 1.49$ & $37.54 \pm 1.61$ & $36.20 \pm 1.49$ & 0.8085 \\
\hline Body weight at 60 days & $56.13 \pm 2.03^{c}$ & $59.00 \pm 2.19^{\mathrm{b}}$ & $63.87 \pm 2.03^{\mathrm{a}}$ & 0.0344 \\
\hline weaning weight & $109.40 \pm 3.41$ & $103.09 \pm 3.99$ & $110.00 \pm 3.82$ & 0.3887 \\
\hline Number of days & $111.2 .93 \pm 2.3$ & $107.58 \pm 2.62$ & $111.77 \pm 2.52$ & 0.404 \\
\hline total gain & $76.30 \pm 3.33$ & $73.33 \pm 3.62$ & $83.89 \pm 4.24$ & 0.1755 \\
\hline $\mathrm{ADG}$ & $0.73 \pm .036$ & $0.68 \pm 0.03$ & $0.80 \pm .036$ & 0.075 \\
\hline
\end{tabular}




\section{DISCUSSION}

\section{Calves health}

Results showed that no pathogenic bacteria (Salmonella sp. and E.coli) were detected in calves' fecal matter. Which indicated that all experimental calves had a good health and a good nutritional condition. Also data indicated that, the probiotic bacteria in calves' fecal matter supplemented with encapsulated and non-encapsulated probiotics wasves' slowly reduced than in control group which indicate that supplementing calves with probiotic bacteria maintains its total count for longer time than control. Agazzi et al. (2014) demonstrated that, the administration of LAB during the first month of life improved gut microbiota and increased the growth performance and some biometric parameters of calves. Gut microbial balance is one of the most important factors in determining good health status in young animals, particularly calves, where the immature immune system is more susceptible to diarrhea and respiratory diseases (Tsuruta et al., 2009). Many studies in farm animals reported that probiotic administration increases the number of beneficial bacteria and decreases the load of pathogens (Corcionivoschi et al., 2010; Signorini et al., 2012), thus positively affecting the function of the animal gut, and ensuring a lower incidence of intestinal and respiratory diseases. Oral administration of LAB-based probiotics has already been recognized as a promoter of intestinal microbial balance and growth performance (Nagashima et al., 2010), a role which it performs by promoting transient proliferation in the digestive tract as well as development of microbial defense against the growth of pathogenic bacteria.

\section{Effect of probiotic supplementation on blood CBC count.}

The data showed that hematology parameters were normal in the three groups which is a sign of good health. In the experimental groups, hemoglobin slightly increased with no significant differences in group supplemented with encapsulated probiotic and control group compared to non-encapsulated probiotic group. In this connection, different results were observed by Stoykov et al. (2001) in an experiment with calves, hemoglobin increased in the experimental group (supplemented with probiotic) and decreased in the control at the end of the test period. The results showed that, calves in all experimental groups showed low hemoglobin (HB) which may be due to high growth rate during young age and milk consumption. Different authors estimated values of hematological variables in calves, they observed that, the values are changing with age (Moosavian et al., 2010; Mohri et al., 2010). Mohri et al. (2007) observed a decrease of HB from birth to the age of 28 days later the values increased with age. In growing calves feeding and rearing system has an important influence on the values of hematological variables (Reece and Hotchkiss, 1987; Scheidegger, 1973). Influence of feeding regime becomes more apparent after the 5th week when consummation of dry food (hay, starter) increases. In this period the values of RBCs, HB increase.

Results showed a significant increase in mixed cell count (MXD) at one month old for calves in the group supplemented with non- encapsulated probiotic than the control and encapsulated probiotic group. The number of leucocytes (WBC) in blood of calves were higher in comparison with adult animals and is more variable as values of other hematological variables, it's clear that their numbers decreased by age as it decreased in number in the second sample than $1^{\text {st }}$ one. Different types of leucocytes have different life spans so their number can change rapidly and blood serves only as transport medium from the place of origin to the place of inflammation (Kraft, 1999). The number of WBC values increased from birth to the age of 10 weeks, then it oscillated more or less to the age of 1 year and is slightly higher as in adult animals (Greatorex, 1954).

Effect of encapsulated and non-encapsulated probiotics supplementation on some blood metabolites

Results revealed that, there were no effects in the total protein and albumin of calves in both the control and the experimental groups, while triglycerides (T.G) tend to be significantly lower in both treated groups than control $(\mathrm{P}<0.07)$. Proteins are important building blocks of all cells and tissues. Proteins are necessary for growth, development, and health of animals. Deficiency of protein impairs both humoral and cell mediated immunity, thus predisposing an animal to diseases Aderemi, (2004). The values obtained were within the normal references as documented in Merck Veterinary Manual (2012) which indicates better health condition of calves. This is consistent with the findings of Adams et al. (2008) who also found no differences between calves receiving probiotics and control animals. Results showed that, blood aspartate amino transferase (AST) concentrations at $1^{\text {st }}$ month were significantly $(\mathrm{P}<0.05)$ high in $\mathrm{T} 1$ and T3 than T2 which indicated better liver health of calves in group T2. Egli and Blum (1998) found that, the activity of AST decreases after the first week, and from the 42nd to 84th day of life it increases slowly. Mohri et al. (2007) observed an increase in AST activity from the 14th to the 84th day of age. Our findings revealed that, calves received probiotics have better health as (alkaline phosphatase) at the $1^{\text {st }}$ month samples ALP1 and at the end of the experiment (ALP2) concentrations tended to be significantly $(\mathrm{P}=0.079, \quad \mathrm{p}=0.055$ 
respectively) higher in the control group than treated non-encapsulated and encapsulated groups. In adult animals, activity of ALP can increase at increased activity of osteoblasts. Activity of ALP is increased at acute and chronic liver diseases (especially cholestatic hepatopathias) and in diseases of bones (rachitis, periostitis), also its clear that ALP was high in the $1^{\text {st }}$ month samples then its activity decreased by age in the $2^{\text {nd }}$ samples before it start to increase again in the $3^{\text {rd }}$ month samples. Knowles et al. (2000) found that the activity of ALP was high in calves after birth then it decreased and remained stable to the age of 60 days, later it decreased slightly more in calves to the age of 6 months (Kraft and Dürr 1999).

Results in Table (5) showed that, calves in group T3 have lower urea 2 concentrations than in T1 and T2 which indicate better kidney function and better health in this group. The concentration of urea in blood depends from nutrition, diagnostically is important also at diseases of kidneys (Kraft \& Dürr, 1999; Jazbec, 1990). Increased concentration of urea in calves' serum may indicates increased catabolism of proteins and appears at long lasting diarrhea (Jazbec, 1990).

Also cholesterol concentration was significantly $(\mathrm{P}<0.05)$ lower in calves in $\mathrm{T} 2$ group than in encapsulated and control groups at the $2^{\text {nd }}$ month samples, while it was lower in both treated groups than control in the $3^{\text {rd }}$ month sample with no significant differences $(\mathrm{P}<0.05)$. Our results were consistent with the findings of Homayouni et al. (2012); Guo et al. (2011); Ooi and Liong (2010) who reported that, a diet rich in probiotics decreases total cholesterol concentration in blood plasma of man but the findings differ from Joy and Samuel (1997), this inconsistence may be due to the use of different strain of probiotics or different experimental condition, time and duration of study. It needs to be confirmed by several studies.

Effect of encapsulated and non-encapsulated isolated probiotics on growth performance of young calves.

Within the first month, the initial results indicated, that the treated calves were having growth rate higher than untreated group. In the second month, the encapsulated probiotics were having a higher growth rate faster than non-capsulated probiotics treated calves than control treatment. At weaning time, encapsulated probiotics treated group was having the highest weaning weight; however, the differences among treatments were not significant. It is supposed that, the main effect for probiotics within this time of calves' growth time is depending on its preventing effect from pathogenic bacteria. It is expected that, with calves' rumen development, the probiotics will have a great effect on rumen fermentation processes, then, better growth performance. Some researchers have reported that, probiotics decrease the incidence of diarrhea (Timmerman et al., 2005), improved body weight gain and feed conversion (Abe et al., 1995) and decreased mortality (Gorgulu et al., 2003).

\section{CONCLUSION}

Probiotic (A1-A2-A3) supplementation improved average daily gain when used encapsulated, using probiotics generally did not adversely affect the levels of blood hematological and biochemical indices of treated calves compared with the controls. They have better health as it lowered the liver enzymes, triglycerides and blood cholesterol. Also higher concentration of MXD and neutrophils in calves received non encapsulated probiotics. Also they are showed higher level of lysozyme activities. Similar studies should be carried out using larger number of animals to assess the effect of these probiotics strains on animal growth performance.

\section{ACKNOWLEDGMENT}

Authors would like to express their thankful to the Science and Technology development fund (STDF), Ministry of Higher Education study through national challenges' target project "production of probiotics and evaluation its impact on dairy and beef cattle performance, ID-10802". Also the authors would like to express their thankful to: S.E. El-Nagar; G.F. Gouda; H.M. Ebeid; H.H. Azzaz; R.M.A. Gawad for their kind help and valuable effort.

\section{REFERENCES}

Abe, F.; Ishibashi, N. and Shimamura, S. (1995): Effect of administration of bifidobacteria and lactic acid bacteria to newborn calves and piglets. J. Dairy Sci. 78, 2838-2846.

Adams, M.C.; Luo, J.; Rayward, D.; King, S.; Gibson, R. and Moghaddam, G.H. (2008): Selection of a novel direct-fed microbial to enhance weight gain in intensively reared calves. Animal Feed Science and Technology, 145:41-52.

Aderemi, F.A. (2004): Effect of replacement of wheat bran with cassava root alleviate supplemented or unsupplemented with enzyme on the haemotology and serum biochemistry of pullet chicks. Tropical Journal of Animal Science, 7: 147-153.

Agazzi, A,; Tirloni, E.; Stella, S.; Maroccolo, S.; Ripamonti, B.; Bersani, C.; Caputo, JM.; Dell'Orto, V.; Rota, N. and Savoini, G. (2014): Effects of species-specific probiotic addition to milk replacer on calf health and 
performance during the first month of life. Annals of Animal Science 14, 101-115.

Batton, C. and Crouch, G. (1977): Enzymatic colorimetric determination of urea. Anal. Chem, 49: 464-469.

Belfield, A. and Goldberg, D.M. (1971): Enzyme. 12,561 .

Bujnakova, D.; Strakova, E. and Kmet, V. (2014): In vitro evaluation of the safety and probiotic properties of Lactobacilli isolated from chicken and calves. Anaerobe 29, 118-127.

Cannon, T.W.; Dye, J.E. and Toutenhoofd, V. (1974): The mechanism of precipitation formation in northeastern Colorado cumulus II. Sailplane measurements. J. Atmos. Sci., 31, 2148-2151, doi

Chávarri, M.; Marañón, I.; Ares, R.; báñez, F.C.; Marzo, F. and Villarán, M. del Carmen. (2010): Microencapsulation of a probiotic and prebiotic in alginate-chitosan capsules improves survival in simulated gastrointestinal conditions. International Journal of Food Microbiology 142 (2010) 185-189.

Corcionivoschi, N.; Drinceanu, D.; Pop, I.; Stack, M.; Stef, D. and Julean, L. (2010): The effect of probiotics on animal health. Journal of Animal Science and Biotechnology 43, 35-41.

Cowan, ST.; Steel, KJ.; Barrow, GI. and Feltham, RKA. (1993): Cowan and Steel's manual for the identification of medical bacteria: Cambridge; New York: Cambridge University Press.

Doumas, B.T.; Watson, W.A. and Briggs, H.G. (1971): Albumin standards and the measurement of serum albumin with bromocresol green. Clin. Chem. Acta 31: 87-97.

Egli, C.P. and Blum, J.W. (1998): Clinical, hematological, metabolic and endocrine traits during the first three months of life of suckling Simmental calves held in a cow-calf operation. Journal of Veterinary Medicine: Series A, Vol. 45, No.2, pp. 99- 118, ISSN 0514-7158.

El-Shafei, K.; Elshaghabee, F.M.F.; El-Sayed, H.S. and Kassem, J.M. (2018): Assessment the viability properities of lactobacillus casei strain using labneh as a carrier. Acta Sci. Pol. Technol. Aliment. 17(3): 267-276.

FAO/WHO, (accessed 21.02.09) http://www.who. int/foodsafety/publications/fs management/ en/probiotics.pdf

Fuller, R. (1997): Introduction. In: Fuller, R. (Ed.), Probiotics 2, Applications and Practical Aspects. Chapman and Hall, London, UK, pp. 1-9

Gorgulu, M.; Siuta, A.; Ongel, E.; Yurtseven, S. and Kutlu, H.B. (2003): Effect of probiotic on growing performance and health of calves. Pak. J. Biol. Sci. 6, 651-654.
Greatorex, J.C. (1954): Studies on the haematology of calves from birth to one year of age. British Veterinary Journal, Vol.110, No.4, (April 1954), pp. 120-138, ISNN 0007-1935

Guo, Z.; Liu, XM.; Zhang, QX.; Shen, Z.; Tian, FW.; Zhang, H.; Sun, ZH.; Zhang, HP. and Chen, $W$. (2011): Influence of consumption of probiotics on the plasma lipid profile: a metaanalysis of randomized controlled trials. Nutrition, Metabalism and Cardiovascular Diseases 21, 844-850.

Homayouni, A.; Payahoo, L. and Azizi, A. (2012): Effects of probiotics on lipid profile: A review. American Journal Food Technology $7251-265$

Jazbec, I. (1990): Klinično laboratorijska diagnostika, I. Jazbec, (Ed.) Pp. 82-206, Veterinarska fakulteta, Ljubljana, Slovenija.

Joy, AD. and Samuel, JJ. (1997): Effect of probiotic supplementation on the performance of broilers. Journal of Veterinary and Animal Sciences 28 10-14.

Knowles, T.G.; Edwards, J.E.; Bazeley, K.J.; Brown, S.N.; Butterworth, A. and Warriss, P.D. (2000): Changes in the blood biochemical and haematological profile of neonatal calves with age. Veterinary Record, Vol.147, No.21, 593-598, ISSN 0042-4900

Kraft, W. and Dürr, U.M. (1999): Leber In: Klinische Labordiagnostik in der Tiermedizin, W. Kraft, U.M. Dürr, (Ed.), pp. 112-133, Schattauer, ISBN 978-3794519422, Stuttgart, Germany

Kraft, W. (1999): Hämatologie. In: Klinische Labordiagnostik in der Tiermedizin, W. Kraft, U.M. Dürr, (Ed.), pp. 43-77, Schattauer, ISBN 978-3794519422, Stuttgart, Germany.

Merck Veterinary Manual Online (2012): (Eds. Aiello, S. E. And Moses, M.A.) Published by Merck Sharp and Dohme Corp., a subsidiary of Merck and Co., Inc., Whitehouse Station, N.J., U.S.A.http:// www.merckmanuals.com/ vet/clinical_pathology_and_procedures/diagn ostic_procedures_for_the_private_practice_la boratory/clinical_biochemistry.html (Accessed 58 on 12/07/13)

Mohri, M.; Sharifi, K. and Eidi, S. (2007): Hematology and serum biochemistry of Holstein dairy calves: Age related changes and comparison with blood composition in adults. Research in Veterinary Science 83, 30-39.

Mohri, M.; Poorsina, S. and Sedaghat, R. (2010): Effect of parenteral supply of iron on RBC parameters, performance, and health in neonatal dairy calves. Biological Trace Element Research, Vol.136, Nol, pp.33-39, ISSN 0163-4984.

Moosavian, H.R.; Mohri, M. and Seifi, H.A. (2010): Effect of parenteral over-supplementation of 
vitamin A and iron on haematology, iron biochemistry, weight gain, and health of neonatal dairy calves. Food and Chemical Toxicology, Vol.48, No.5, pp.1316-1320, ISSN 0278-6915.

Nagashima, K.; Yasokawa, D.; Abe, K.; Nakagawa, R.; Kitamura, T.; Miura, T. and Kogawa, S. (2010): Effect of a Lactobacillus species on incidence of diarrhea in calves and change of the microflora associated with growth. Bioscience of Microbiota 29, 97-110.

Ooi, LG. and Liong, MT. (2010): Cholesterollowering effects of probiotics and prebiotics: a review of in vivo and in vitro findings. International Journal of Molecular Science 11 2499-2522.

Paul, D.; Fey, Ph.D.; Thomas, J.; Safranek, M.D.; Mark, E.; Rupp, M.D.; Eileen, F.; Dunne, M.D.; M.P.H.; Efrain Ribot, Ph.D.; Peter, C.; Iwen, M.S.; Patricia, A.; Bradford, Ph.D.; Frederick, J.; Angulo, D.V.M., Ph.D. and Steven H. Hinrichs, M.D. (2000): Ceftriaxone-Resistant Salmonella Infection Acquired by a Child from Cattle The New Engl. J. Med. ; 342:1242-1249.

Rajarman, V.; Nonnecke, B.J.; Franklin, S.T.; Hammell, D.C. and Horst, R.L. (1998): Effect of vitamin A and E supply on nitric oxide production by blood mononuclear leukocyte from neonatal calves feed milk replacers. J. Dairy Sci.; 81:3278-3285.

Reece, W.O. and Hotchkiss, D.K. (1987): Blood studies and performance among calves reared by different methods. Journal of Dairy Science, Vol.70, No.8, pp. 1601- 1611, ISSN 0022-0302.

Rivera, J.D.; Duff, G.C.; Galyean, M.L.; Walker, D.A. and Nunnery, G.E. (2002): Effects of supplemental vitamin $\mathrm{E}$ on performance, health and humoral immune response of beef cattle. J. Anim. Sci. 80:933-941

Scheidegger, H.R. (1973): Veränderungen des Roten Blutbildes und der serumeisenkonzentration bei Simmentaler Kälbern. Schweizer Archiv für Tierheilkunde, Vol.115, No.11, pp. 483497, ISNN 0036-7281

Schultz, L.A. (1987): Methods in clinical chemistry. The C.V. Mosby Co. St. Louis. 742-746.

Spencer, K. and Price, CP. (1980): A review of Non-enzyme mediated reaction and their application to centrifugal analyzers. IN centrifugal analyzers in clinical chemistry, $\mathrm{CP}$ Price, $\mathrm{K}$ Spencer, editors, Praeger publishers, New York, p231.

Signorini, ML.; Zbrun, MV.; Sequeira, GJ.; Rosmini, MR. and Frizzo, LS. (2012): Impact of probiotic administration on the health and fecal microbiota of young calves: A metaanalysis of randomized controlled trials of lactic acid bacteria. Research in Veterinary Science 93, 250-258.

Stanton, AL. (2014): Finding the future now Health, genomics, and calves. In: ADSAASAS Midwest Meeting. American Society of Animal Science. 18-19.

Stein, G. and Athans, M. (1987): The LQR/LTR Procedure for Multivariable Feedback Control Design IEEE Transactions on Automatic Control, AC-32 (2) pp. 105-113.

Stoykov, P.; Simeonova, S.; Savova, T.; Nikolov, Z.; Florov, I. and Ivanov, M. (2001): A study on the viability of calves received in addition to natural whole milk fermented milk product obtained with bacteria strain Lactobacillus Casei 169. Animal Science, 3-4: 125-127 (Bg).

Timmerman, H.M.; Mudler, L.; Everts, H. and Vanespan, D.C. (2005): Health and growth of veal calves fed milk replacer with or without probiotics. J. Dairy Sci. 75:894-899.

Timmerman, H.M.; Koning, C.J.; Mulder, L.; Rombouts, F.M. and Beynen, A.C. (2004): Monostrain, multistrain and multispecies probiotics-A comparison of functionality and efficacy. Int. J. Food Microbiol. 96, 219-233.

Tsuruta, T.; Inoue, R.; Tsukahara, T.; Matsubara, N.; Hamasaki, M.; Ushida, K. (2009): A cell preparation of Enterococcus fecalis strain EC-12 stimulates the luminal immunoglobulin A secretion in juvenile calves. Animal Science Journal 80, 206-211.

Walter, J. (2005): The microecology of lactobacilli in the gastrointestinal tract. In: Tannock, G. (Ed.), Probiotics and Prebiotics, Scientific Aspects. Caister Academic Press, UK.

Young, DS. (1990): Effects of drugs on clinical laboratory tests. Third edition.3:6-12. 


\section{تاثير استخدام البروبيوتك بكتريا المكبسلة والغير مكبسلة على اداء العجول الرضية \\ محد سامي الجارحي ، منح ذ/بإ ، هدا السبل ، حازم رفعت الشربف، نصر البرديني}

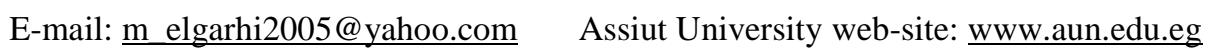

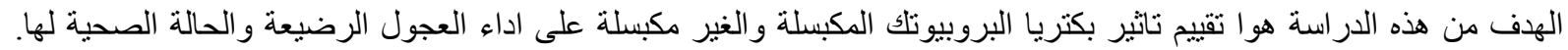

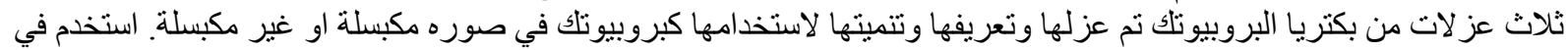

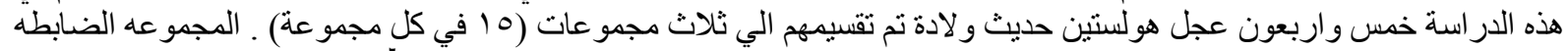

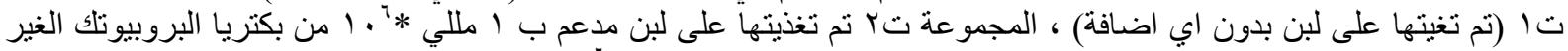

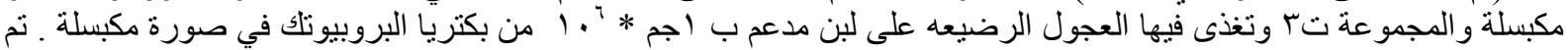

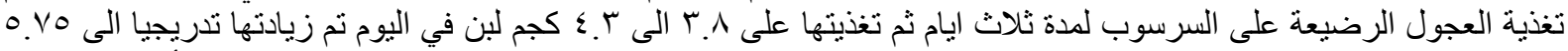

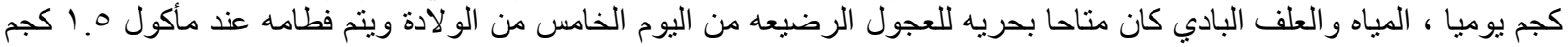

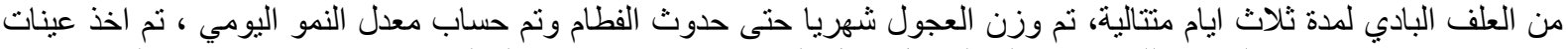

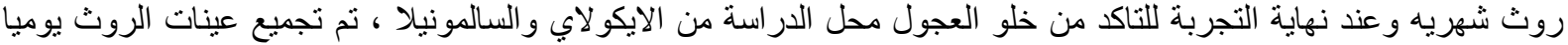

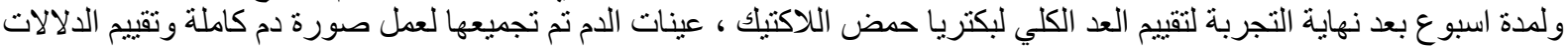

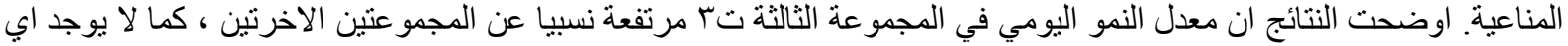

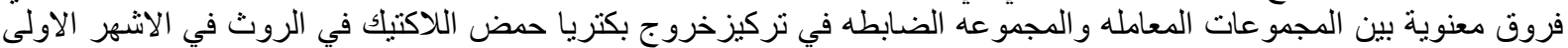

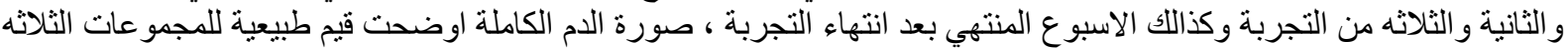

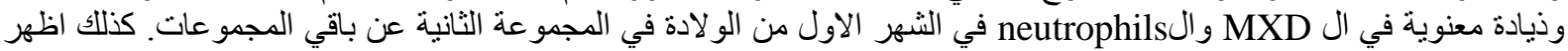

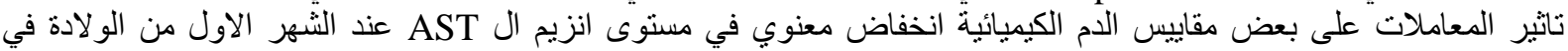

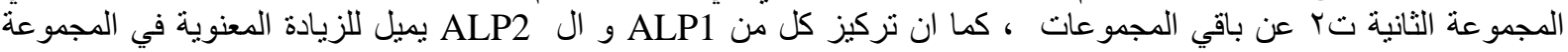

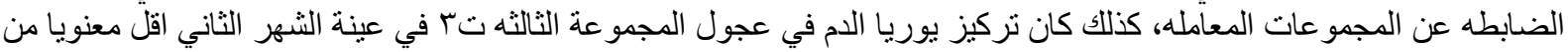

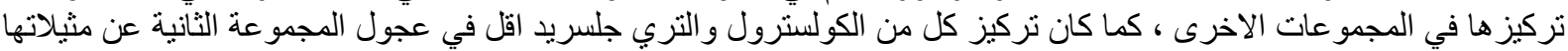

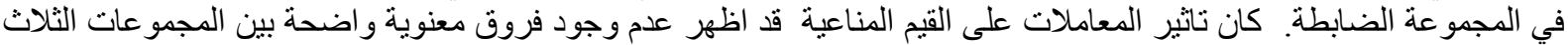

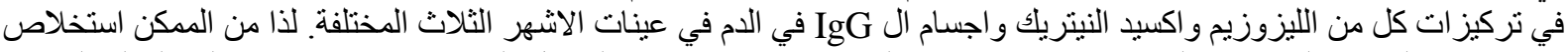

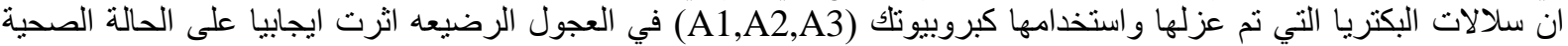

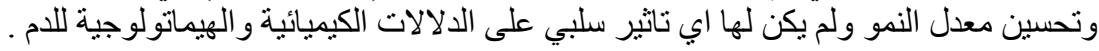
الكلمات الدالة : البروبيوتلك ، اداء العجول الرضيعة ، المناعة 